\title{
Evaluation of antinociceptive effect of methanolic extract of leaves of Crataeva nurvala Buch.-Ham.
}

\author{
Md Moniruzzaman ${ }^{1}$ and Mohammad Zafar Imam² $^{2^{*}}$
}

\begin{abstract}
Background: Crataeva nurvala Buch.-Ham. (Family: Capparidaceae) is widely used as anti-inflammatory, contraceptive, laxative, lithotropic, febrifuge and as tonic in traditional medicine. This study evaluated the antinociceptive effect of the methanolic extract of the leaves of Crataeva nurvala (MECN).

Methods: The antinociceptive activity was investigated using heat-induced (hot-plate and tail-immersion test) and chemical-induced (acetic acid, formalin and glutamic acid) nociception models in mice at different doses $(50,100$, and $200 \mathrm{mg} / \mathrm{kg}$, p.o.) of MECN. Morphine sulphate (5 mg/kg, i.p.) and diclofenac sodium (10 mg/kg, i. p.) were used as reference analgesic drugs.

Results: MECN produced significant dose-dependent antinociception when assessed using hot plate test, tail immersion test and acetic acid-induced abdominal writhing test (65.55\%). Likewise, MECN at similar doses produced significant dose-dependent inhibition in both neurogenic (50.82\%) and inflammatory pain (73.53\%) induced by intraplantar injection of formalin (2.5\% formalin, $20 \mu \mathrm{l} /$ paw). Besides, MECN also significantly inhibited the glutamate-induced $(10 \mu \mathrm{M} /$ paw) pain in mice (74.68\%). It was demonstrated that pretreatment with naloxone ( $2 \mathrm{mg} / \mathrm{kg}$, i.p.) significantly reversed antinociception produced by MECN in hot plate and tail immersion test suggesting the involvement of opioid receptor. In addition, administration of glibenclamide (10 mg/kg, i.p.), an ATP-sensitive $\mathrm{K}^{+}$channel antagonist could not reverse antinociceptive activity induced by MECN.
\end{abstract}

Conclusion: The results suggest that MECN possesses antinociceptive activity involving inhibition of opioid system as well as the glutamatergic system supporting its traditional uses.

Keywords: Antinociceptive, Crataeva nurvala, Capparidaceae, Opioid system, Glutamatergic system, Medicinal plants

\section{Background}

Crataeva nurvala Buch.-Ham., a common plant in Bangladesh locally known as Borun or Bonna, is a medium sized branched deciduous tree which grows throughout the bank of rivers, canals, lakes and roadsides of tropical, and sub-tropical countries of the world [1]. For a long period of time this plant has been used in the traditional medicine of Bangladesh as anti-inflammatory, contraceptive, laxative, lithotropic, febrifuge and tonic. It is also useful in the treatment of kidney stone, bladder stone, vomiting, gastric irritation and rheumatic fever [2]. Besides, $C$. nurvala is used to treat waste elimination and breathing problems, metabolic disorders, joint lubrication, skin moisture, wound healing, memory loss, heart and

\footnotetext{
* Correspondence: zafarimam@gmail.com

Department of Pharmacy, Stamford University Bangladesh, 51 Siddeswari Road, Dhaka 1217, Bangladesh

Full list of author information is available at the end of the article
}

lung weakness and weak immune system. The bark is also used in Unani system as appetite promoter and to decrease bile and phlegm secretion [3]. Preliminary phytochemical screening revealed that the leaves contain L-stachydrine, dodecanoic anhydride, methyl pentacosanoate, kaemferol- $O-\alpha$-D-glucoside and quercitin-3$O-\alpha$-D-glucoside16 [4]. The stem bark, fruit and root contain saponins, flavonoids, sterols and glucosilinates, friedelin, cadabicine diacetate, lupeol, betulinic acid and diosgenin, glucocapparin, triacontane, triacontanol, cetyl and ceryl alcohol, pentadecane, octanamide, 12-tricosanone and friedelin, rutin, quercitin, varunol and $\beta$-sitosterol [5]. It was reported that, the compound lupeol isolated from $C$. nurvala stem bark and its ester lupeol linoleate have shown anti-inflammatory activity in complete Freund's adjuvant induced arthritic rats [6]. Lupeol also increased glutathione and catalase 
activities that are indicative of its antioxidant properties [7]. Besides, the extract from the stem bark also showed antidiabetic activity in alloxan-induced diabetic rats [8].

To our best knowledge, there is no report about the antinociceptive activity of $C$. nurvala leaves. So the methanolic extract of $C$. nurvala leaves was investigated for it's potential antinociceptive activity in different experimental models in mice.

\section{Methods}

\section{Plant material and extraction}

The leaves of $C$. nurvala were collected from the road side plants naturally grown at Muradnagar in Comilla district of Bangladesh in October 2012. The collected samples were identified by Bushra Khan, Principal Scientific Officer, Bangladesh National Herbarium, Mirpur, Dhaka, Bangladesh. A voucher specimen (DACB: 37942) has been deposited in the Herbarium for further reference. Powdered dried leaves (250 g) were macerated with $500 \mathrm{ml}$ of methanol with occasional stirring at $25 \pm 2^{\circ} \mathrm{C}$ for 3 days. The extract was then filtered using a Buchner funnel and a sterilized cotton filter. The solvent was completely removed by rotary evaporator and $10.31 \mathrm{~g}$ extract (yield 4.12\%) was obtained. This crude extract was used for the acute toxicity and antinociceptive activity studies.

\section{Animals}

Swiss albino mice (20-25 g) were collected from Animal Resources Branch of the International Center for Diarrheal Disease Research, Bangladesh (icddr,b). The animals were kept in standard laboratory conditions (relative humidity 55-60\%; room temperature $25 \pm 2^{\circ} \mathrm{C}$; $12 \mathrm{~h}$ light/dark cycle) and were provided with standard diet (icddr,b formulated) and clean water ad libitum during acclimatization period. The animals were acclimatized to the laboratory environment for a period of 14 days prior performing the experiments. The animals were fasted overnight before the experiments. All the experimental animals were treated following the Ethical Principles and Guidelines for Scientific Experiments on Animals (1995) formulated by The Swiss Academy of Medical Sciences and the Swiss Academy of Sciences. All experimental protocols were approved by the Ethics Committee of Stamford University Bangladesh (SUB/ IAEC/12.03).

\section{Drugs and treatments}

The standard drug morphine sulphate $(5 \mathrm{mg} / \mathrm{kg})$ used in hot plate and tail immersion tests and diclofenac sodium $(10 \mathrm{mg} / \mathrm{kg})$ in writhing and licking tests were administered intraperitoneally $15 \mathrm{~min}$ before the experiments while the animals in control group received vehicle
(DMSO : $\mathrm{H}_{2} \mathrm{O}$ in 2:1 ratio) orally at the dose of $10 \mathrm{ml} / \mathrm{kg}$ body weight $30 \mathrm{~min}$ before the experiments. MECN was dissolved in DMSO and $\mathrm{H}_{2} \mathrm{O}$ in 2:1 ratio respectively and orally administered to the test animals 30 min before the experiments at the doses of 50, 100, and $200 \mathrm{mg} / \mathrm{kg}$ body weight in both the chemical- and heat-induced pain models. Naloxone, a non-selective opioid receptor antagonist, was injected intraperitoneally at $2 \mathrm{mg} / \mathrm{kg}$ dose $15 \mathrm{~min}$ before the administration of morphine sulphate or MECN (50, 100, and $200 \mathrm{mg} / \mathrm{kg}$ ) to investigate the involvement of opioid receptor system. Besides, an ATP-sensitive $\mathrm{K}^{+}$channel inhibitor, glibenclamide $(10 \mathrm{mg} / \mathrm{kg})$ was also injected intraperitoneally to verify the involvement of ATP-sensitive $\mathrm{K}^{+}$ channel pathway.

\section{Acute toxicity test}

The test animals were divided into control and three test groups each containing five animals. MECN was administered p.o. at the doses of 1,000 2,000 and 3,000 mg/kg. The mice were allowed food and water ad libitum and all animals were observed for toxic symptoms and mortality for the next $72 \mathrm{~h}$ [9].

\section{Antinociceptive analysis Hot plate test}

The mice that showed forepaw licking, withdrawal of the paw(s) or jumping response within $15 \mathrm{~s}$ on hot plate kept at a temperature of $50 \pm 0.5^{\circ} \mathrm{C}$ were selected for this study $24 \mathrm{~h}$ prior to the experiment. Mice were fasted overnight with water given ad libitum. The animals were treated with morphine or extract and were placed on Eddy's hot plate kept at a temperature of $50 \pm 0.5^{\circ} \mathrm{C}$. A cut off period of $20 \mathrm{~s}$ was maintained to avoid paw tissue damage [10]. The response in the form of forepaw licking, withdrawal of the paw(s) or jumping was recorded at 30, 60, 90, and $120 \mathrm{~min}$ following the treatment. Then the \% MPE was calculated from the latency periods.

\section{Tail immersion test}

To evaluate the central analgesic property the tail immersion test was performed. This procedure is based on the observation that morphine like drugs prolongs the tail withdrawal time from hot water in mice [11]. One to two $\mathrm{cm}$ of tail of the mice pretreated with morphine or MECN were immersed in warm water kept constant at $54 \pm 0.5^{\circ} \mathrm{C}$. The latency between tail immersion and deflection of tail was recorded. A latency period of $20 \mathrm{~s}$ was maintained to avoid tail tissue damage in mice. The latency period of the tailwithdrawal response was taken as the index of antinociception and was determined at 30, 60, 90, and 120 min after the administration of the drug and 
extract. Then the \% MPE was calculated from the latency periods.

\section{Acetic acid-induced writhing test}

In this test, the mice were treated with drug or extract and then the writhing was induced by injecting $0.6 \%$ acetic acid after 15 and $30 \mathrm{~min}$, respectively, at the dose $10 \mathrm{ml} / \mathrm{kg}$ body weight. After five minutes the mice were observed and the number of writhing was counted for $30 \mathrm{~min}$ [12]. The contractions of the abdomen, elongation of the body, twisting of the trunk and/or pelvis ending with the extension of the limbs were considered as complete writhing.

\section{Formalin-induced nociception}

Mice were injected with $20 \mu \mathrm{l}$ of $2.5 \%$ formalin solution (equivalent to $0.92 \%$ formaldehyde) made up in saline, into the sub-plantar region of the right hind paw $60 \mathrm{~min}$ after MECN treatment and $15 \mathrm{~min}$ after injection of Diclofenac sodium. Licking of the injected paw was recorded as nociceptive response at $0-5 \mathrm{~min}$ (neurogenic phase) and 15-30 min (inflammatory phase) after formalin injection $[13,14]$.

\section{Glutamate-induced nociception}

$20 \mu \mathrm{L}$ of glutamate $(10 \mu \mathrm{M} / \mathrm{paw})$ was injected into the ventral surface of the right hind paw of the mice $30 \mathrm{~min}$ after MECN treatment and $15 \mathrm{~min}$ after injection of Diclofenac sodium. The mice were observed for $15 \mathrm{~min}$ following glutamate injection. The number of licking of its injected paw was indicative of nociception [15].

\section{Analysis of the possible mechanism of action of MECN Involvement of opioid system}

The possible participation of the opioid system in the antinociceptive effect of MECN was examined by injecting naloxone hydrochloride $(2 \mathrm{mg} / \mathrm{kg}$ i.p.), a nonselective opioid receptor antagonist, $15 \mathrm{~min}$ prior to the administration of either morphine or MECN. Then the hot plate and tail immersion latencies were sequentially measured at pretreatment, 30, 60, 90 and 120 min with the same cut off time of $20 \mathrm{~s}$ for the safety of animals [16].

\section{Involvement of ATP-sensitive $K^{+}$channel pathway}

Possible contribution of $\mathrm{K}^{+}$channel in the antinociceptive effect of MECN was evaluated by using the method described previously $[17,18]$. The mice were pretreated with glibenclamide $(10 \mathrm{mg} / \mathrm{kg})$, an ATP-sensitive $\mathrm{K}^{+}$ channel inhibitor, intraperitonially $15 \mathrm{~min}$ before administration of either diclofenac sodium or MECN. The mice were challenged with i.p. injection of $0.6 \%$ acetic acid, $30 \mathrm{~min}$ post-treatment. Following the injection of acetic acid, the animals were immediately placed in a chamber and the number of writhing was recorded for $30 \mathrm{~min}$, starting from 5 min post injection.

\section{Statistical analysis}

The results are presented as Mean \pm SEM. The statistical analysis was performed using one way analysis of variance (ANOVA) followed by Dunnett's post hoc test or Bonferroni's test as appropriate useing SPSS

Table 1 Antinociceptive effect of methanolic extract of $C$. nurvala leaves, morphine, and reversal effect of naloxone in hot plate test

\begin{tabular}{|c|c|c|c|c|c|c|}
\hline \multirow[t]{2}{*}{ Treatment } & \multirow[t]{2}{*}{ Dose $(\mathrm{mg} / \mathrm{kg})$} & \multicolumn{5}{|c|}{ Response time (s) (\%MPE) } \\
\hline & & Pretreatment & $30 \mathrm{~min}$ & $60 \mathrm{~min}$ & $90 \mathrm{~min}$ & $120 \mathrm{~min}$ \\
\hline Control & $0.1 \mathrm{ml} / \mathrm{mouse}$ & $5.87 \pm 0.20$ & $6.30 \pm 0.13$ & $6.72 \pm 0.09$ & $8.62 \pm 0.32$ & $9.34 \pm 0.25$ \\
\hline Morphine & 5 & $6.67 \pm 0.30$ & $12.70 \pm 0.51^{*}(45.23)$ & $14.75 \pm 1.03^{*}(60.64)$ & $15.70 \pm 0.86^{*}(67.77)$ & $15.84 \pm 0.94(68.82)$ \\
\hline MECN & 50 & $5.72 \pm 0.74$ & $7.84 \pm 0.63(14.90)$ & $8.31 \pm 0.43(18.17)$ & $10.19 \pm 0.60(31.35)$ & $10.37 \pm 0.51(32.58)$ \\
\hline MECN & 100 & $6.71 \pm 0.48$ & $8.98 \pm 0.56^{* *}(17.04)$ & $9.66 \pm 0.12^{* *}(22.16)$ & $13.16 \pm 0.89^{* *}(48.52)$ & $13.06 \pm 1.66(47.73)$ \\
\hline MECN & 200 & $5.83 \pm 0.66$ & $9.54 \pm 0.21^{*}(26.22)$ & $11.74 \pm 0.72^{*}(41.70)$ & $13.86 \pm 1.12^{*}(56.69)$ & $13.71 \pm 1.78(55.60)$ \\
\hline NLX & 2 & $7.22 \pm 0.34$ & $7.05 \pm 0.18$ & $6.85 \pm 0.13$ & $6.71 \pm 0.29$ & $5.30 \pm 0.36$ \\
\hline $\mathrm{NLX}+$ Control & $2+0.1 \mathrm{ml} /$ mouse & $5.93 \pm 0.27$ & $6.15 \pm 0.10$ & $6.54 \pm 0.19$ & $8.01 \pm 0.37$ & $8.38 \pm 0.69$ \\
\hline NLX + Morphine & $2+5$ & $6.41 \pm 0.37$ & $7.25 \pm 0.40^{\mathrm{a}}(6.24)$ & $7.65 \pm 0.16^{a}(9.15)$ & $8.86 \pm 0.26^{\mathrm{a}}(18.02)$ & $8.96 \pm 0.19^{a}(18.82)$ \\
\hline $\mathrm{NLX}+\mathrm{MECN}$ & $2+50$ & $5.98 \pm 0.61$ & $6.31 \pm 0.38(2.37)$ & $7.41 \pm 0.22(10.17)$ & $9.13 \pm 0.79(22.44)$ & $9.71 \pm 0.46$ (26.59) \\
\hline $\mathrm{NLX}+\mathrm{MECN}$ & $2+100$ & $5.95 \pm 0.81$ & $6.49 \pm 0.76^{b}(3.80)$ & $7.93 \pm 0.46(14.05)$ & $9.53 \pm 0.61(25.49)$ & $10.08 \pm 1.00(29.36)$ \\
\hline $\mathrm{NLX}+\mathrm{MECN}$ & $2+200$ & $6.18 \pm 0.96$ & $7.04 \pm 0.41^{\complement}(6.25)$ & $8.75 \pm 1.02^{c}(18.64)$ & $9.95 \pm 1.33^{c}(27.30)$ & $10.14 \pm 0.59(28.69)$ \\
\hline
\end{tabular}

Each value is presented as the mean $\pm \operatorname{SEM}(n=5)$. MECN = Methanolic extract of. Crataeva nurvala leaves; NLX $=$ Naloxone.

${ }^{*} p<0.001$ compared with the control group (Dunnett's test).

${ }^{* *} p<0.01$ compared with the control group (Dunnett's test).

${ }_{p} p<0.001$ compared with the morphine group (Bonferroni's test).

${ }^{\mathrm{b}} p<0.05$ compared with the MECN 100 group (Bonferroni's test).

${ }^{c} p<0.05$ compared with the MECN 200 group (Bonferroni's test). 
Table 2 Antinociceptive effect of methanolic extract of $C$. nurvala leaves, morphine, and reversal effect of naloxone in tail immersion test

\begin{tabular}{|c|c|c|c|c|c|c|}
\hline \multirow[t]{2}{*}{ Treatment } & \multirow[t]{2}{*}{ Dose(mg/kg) } & \multicolumn{5}{|c|}{ Response times (s) (\%MPE) } \\
\hline & & Pretreatment & $30 \mathrm{~min}$ & $60 \mathrm{~min}$ & $90 \mathrm{~min}$ & $120 \mathrm{~min}$ \\
\hline Control & $0.1 \mathrm{ml} / \mathrm{mouse}$ & $1.78 \pm 0.17$ & $2.01 \pm 0.19$ & $2.44 \pm 0.09$ & $2.77 \pm 0.30$ & $2.93 \pm 0.29$ \\
\hline Morphine & 5 & $1.62 \pm 0.10$ & $3.11 \pm 0.37^{*}(8.13)$ & $3.95 \pm 0.27^{*}(12.66)$ & $4.35 \pm 0.28^{*}(14.87)$ & $4.17 \pm 0.24(13.88)$ \\
\hline MECN & 50 & $1.75 \pm 0.11$ & $2.13 \pm 0.11(2.13)$ & $2.32 \pm 0.04(3.16)$ & $2.79 \pm 0.19(5.70)$ & $2.96 \pm 0.06(6.67)$ \\
\hline MECN & 100 & $1.91 \pm 0.13$ & $2.63 \pm 0.33(3.98)$ & $3.06 \pm 0.53(6.36)$ & $4.15 \pm 0.59 *(12.37)$ & $4.28 \pm 0.59 *(13.08)$ \\
\hline MECN & 200 & $1.81 \pm 0.14$ & $3.03 \pm 0.26^{*}(6.67)$ & $3.75 \pm 0.17^{*}(10.66)$ & $4.26 \pm 0.34^{*}(13.46)$ & $4.58 \pm 0.26^{*}(15.20)$ \\
\hline$N L X$ & 2 & $1.91 \pm 0.11$ & $2.23 \pm 0.17$ & $2.29 \pm 0.19$ & $2.30 \pm 0.17$ & $2.22 \pm 0.32$ \\
\hline $\mathrm{NLX}+$ Control & $2+0.1 \mathrm{ml} /$ mouse & $1.68 \pm 0.15$ & $1.97 \pm 0.08$ & $2.11 \pm 0.10$ & $2.14 \pm 0.13$ & $2.27 \pm 0.16$ \\
\hline NLX + Morphine & $2+5$ & $1.94 \pm 0.18$ & $2.08 \pm 0.08(0.80)$ & $2.52 \pm 0.05^{\mathrm{a}}(3.26)$ & $2.95 \pm 0.14^{\mathrm{a}}(5.64)$ & $3.11 \pm 0.11(6.50)$ \\
\hline $\mathrm{NLX}+\mathrm{MECN}$ & $2+50$ & $1.91 \pm 0.16$ & $2.08 \pm 0.07(0.94)$ & $2.11 \pm 0.08$ (1.12) & $2.13 \pm 0.32(1.22)$ & $2.20 \pm 0.38(1.61)$ \\
\hline$N L X+M E C N$ & $2+100$ & $1.78 \pm 0.11$ & $2.10 \pm 0.13(1.75)$ & $2.21 \pm 0.11(2.38)$ & $2.32 \pm 0.04^{b}(2.99)$ & $2.71 \pm 0.15(5.12)$ \\
\hline $\mathrm{NLX}+\mathrm{MECN}$ & $2+200$ & $1.95 \pm 0.11$ & $2.20 \pm 1.10(1.38)$ & $2.41 \pm 0.14^{c}(2.56)$ & $2.55 \pm 0.07^{\complement}(3.33)$ & $2.80 \pm 0.06^{c}(4.69)$ \\
\hline
\end{tabular}

Each value is presented as the mean $\pm \operatorname{SEM}(n=5)$. MECN = Methanolic extract of. Crataeva nurvala leaves; NLX $=$ Naloxone.

${ }^{*} p<0.05$ compared with the control group (Dunnett's test).

${ }^{a} p<0.05$ compared with the morphine group (Bonferroni's test).

${ }^{\mathrm{b}} p<0.05$ compared with the MECN 100 group (Bonferroni's test).

$c p<0.01$ compared with the MECN 200 group (Bonferroni's test).

11.5 software. A p value $<0.05$ was considered significant. The results of the tail immersion and hot plate tests were given with percentage of the maximal possible effect (\%MPE), which was calculated as follows:

$$
\begin{aligned}
\% \mathrm{MPE}= & {[(\text { postdrug latency })-(\text { predrug latency }) /(\text { cutoff time })} \\
& -(\text { predrug latency })] \times 100
\end{aligned}
$$

\section{Results and discussion}

\section{Acute toxicity test}

The present study demonstrated that oral administration of the MECN at the doses of 1,000 2,000 and 3,000 mg/kg did not show any mortality, behavioral changes (sedation, excitability) or allergic manifestations during the $72 \mathrm{~h}$ observation period after administration. Therefore, it can be assumed that MECN possess low toxicity profile and the $\mathrm{LD}_{50}$ is more than $3,000 \mathrm{mg} / \mathrm{kg}$.

\section{Hot plate and tail immersion tests}

The hot plate and tail immersion methods are useful for the evaluation of centrally acting analgesics which are known to elevate the pain threshold of mice towards heat [19]. These tests are useful to determine the involvement of the opioid receptors in the action of the narcotic drugs or other analgesic agents that give effect in this pathway [20]. In our study we have found the maximum effects of the MECN at all doses reached at 30-90 min (Tables 1 and 2). In both heat-induced methods MECN particularly at 100 and $200 \mathrm{mg} / \mathrm{kg}$ doses significantly prolonged the latency period $(\mathrm{P}<0.05)$. The ability of the extract to prolong the reaction latency suggests that the extract is endowed with central analgesic activity.

\section{Acetic acid writhing test}

The acetic acid induced writhing test is widely used for antinociceptive screening and involves local peritoneal

Table 3 Antinociceptive effect of MECN leaf in acetic acid-induced abdominal writhing test in mice

\begin{tabular}{llll}
\hline Treatment & Dose $(\mathbf{m g} / \mathbf{k g})$ & \multicolumn{2}{c}{ Responses } \\
\cline { 3 - 4 } & & Number of writhing (Mean \pm SEM) & - \\
\hline Control & $0.1 \mathrm{ml} /$ mouse & $65.90 \pm 2.05$ & 69.65 \\
Diclofenac sodium & 10 & $20.00 \pm 0.79^{*}$ & 10.32 \\
MECN & 50 & $59.10 \pm 3.74$ & 51.14 \\
MECN & 100 & $32.20 \pm 1.41^{*}$ & 65.55 \\
MECN & 200 & $22.70 \pm 0.91^{*}$ & \\
\hline
\end{tabular}

Values are expressed as Mean \pm SEM $(n=5) ;{ }^{*}$ denotes $p<0.001$ compared with control group (Dunnett's test). 
Table 4 Antinociceptive effect of methanolic extract of $C$. nurvala leaf in formalin test in mice

\begin{tabular}{|c|c|c|c|c|c|}
\hline \multirow[t]{3}{*}{ Treatment } & \multirow[t]{3}{*}{ Dose (mg/kg) } & \multirow{2}{*}{\multicolumn{2}{|c|}{$\begin{array}{l}\text { Licking number } \\
\text { (Mean } \pm \text { SEM) }\end{array}$}} & \multirow{2}{*}{\multicolumn{2}{|c|}{$\%$ Inhibition }} \\
\hline & & & & & \\
\hline & & Early phase & Late phase & Early phase & Late phase \\
\hline Control & $0.1 \mathrm{ml} / \mathrm{mouse}$ & $143.20 \pm 2.11$ & $149.60 \pm 3.61$ & - & - \\
\hline Diclofenac sodium & 10 mg/kg & $28.40 \pm 1.36^{*}$ & $7.40 \pm 0.51^{*}$ & 80.17 & 95.05 \\
\hline MECN & $50 \mathrm{mg} / \mathrm{kg}$ & $126.60 \pm 7.52$ & $87.40 \pm 4.50^{*}$ & 11.59 & 41.58 \\
\hline MECN & 100 mg/kg & $111.40 \pm 4.58^{*}$ & $50.20 \pm 2.44^{*}$ & 22.21 & 66.44 \\
\hline MECN & 200 mg/kg & $71.20 \pm 0.97^{*}$ & $39.60 \pm 2.89^{*}$ & 50.28 & 73.53 \\
\hline
\end{tabular}

Values are expressed as Mean \pm SEM $(n=5) ;{ }^{*}$ denotes $p<0.001$ compared with control group (Dunnett's test).

receptors (cholinergic and histamine receptor) as well as the mediators of acetylcholine and histamine [21]. In the abdominal tissues acetic acid injection produces peritoneal inflammation, which triggers a response characterized by writhing [22]. Such types of responses are induced by the release of endogenous mediators of pain such as prostaglandins, bradykinine and cytokines (TNF- $\alpha$, IL- $1 \beta$ and IL-8) that stimulate the nociceptive neurons, which are sensitive to non steroidal antiinflammatory drugs (NSAIDs) and opioids [23]. In our study, MECN inhibitied the acetic acid induced writhing in a dose dependent manner. MECN at the dose of $200 \mathrm{mg} / \mathrm{kg}$ and $100 \mathrm{mg} / \mathrm{kg}$ displayed the highest significant $(\mathrm{P}<0.001)$ inhibition of writhing $(65.55 \%$ and $51.14 \%)$ that are comparable to the antinociceptive activity of diclofenac sodium (69.65\%) (Table 3). These responses can be described as a typical model of inflammatory pain in which the sensory neurons are depolarized by directly activating a non-selective cationic channel of cutaneous, visceral and other types of peripheral afferent $C$ fibers [24]. Thus, the significant reduction in the number of acetic acid-induced writings by MECN indicates the antinociceptive potential of this plant and confirms its traditional use for the relief of inflammatory pain.

\section{Formalin induced nociception}

In formalin test, intraplantar injection of formalin comprises two phases of painful sensitivity. In the first phase the neurogenic pain is caused by direct activation of type $\mathrm{C}$ nociceptive nerve endings, releasing neuropeptides such as substance P, among others. On the other hand, the second phase is characterized as inflammatory pain, related to the release of chemical mediators such as histamine, serotonin, bradykinin, prostaglandins and excitatory amino acids, which can be inhibited by painkillers and anti-inflammatory drugs [25-27]. In our study, MECN produced antinociception in both phases of the formalin test, although the effect was more pronounced in the inflammatory phase (Table 4). Therefore, it is reasonable that it has the same antinociceptive activity as central analgesic drugs. Moreover, the antinociceptive effect of MECN on the later phase suggested the antinociceptive potential could involve the anti-inflamatory property.

\section{Glutamate induced nociception}

In addition, to investigate the involvement of glutamatergic receptors in this antinociception, we used L-glutamic acid to produce nociception. We found that, MECN significantly inhibited the noxious stimuli by L-glutamic acid in a dose dependent manner. These inhibitions are comparable to the reference drug diclofenac sodium, which produces $68.45 \%$ inhibition of the pain (Table 5). The $200 \mathrm{mg} / \mathrm{kg}$ produced $74.68 \%$ inhibition of the nociception that is higher than the effect produced by the reference drug. Thus it can be assumed that the MECN inhibited the excitatory amino acids, $\mathrm{PGE}_{2}$ (Prostaglandin

Table 5 Effect of methanolic extract of $C$. nurvala leaf in Glutamate-induced nociception in mice

\begin{tabular}{llll}
\hline Treatment & Dose $(\mathbf{m g} / \mathbf{k g})$ & \multicolumn{2}{c}{ Responses } \\
\cline { 3 - 4 } & & Number of licking (Mean \pm SEM) & 0 \\
\hline Control & $0.1 \mathrm{ml} /$ mouse & $157.20 \pm 4.87$ & 68.45 \\
Diclofenac sodium & 10 & $49.60 \pm 1.08^{*}$ & 62.09 \\
MECN & 50 & $59.60 \pm 2.25^{*}$ & 68.83 \\
MECN & 100 & $49.00 \pm 2.39^{*}$ & 74.68 \\
MECN & 200 & $39.80 \pm 3.53^{*}$ & \\
\hline
\end{tabular}

Values are expressed as Mean \pm SEM $(n=5) ;{ }^{*}$ denotes $p<0.001$ compared with control group (Dunnett's test). 
Table 6 Effect of methanolic extract of C. nurvala leaf on Involvement of ATP-sensitive $\mathrm{K}^{+}$channel pathway

\begin{tabular}{llll}
\hline Treatment & Dose $(\mathbf{m g} / \mathbf{k g})$ & \multicolumn{2}{c}{ Responses } \\
\cline { 3 - 4 } & & Number of writhing (Mean \pm SEM) & - \\
Control & $0.1 \mathrm{ml} /$ mouse & $73.90 \pm 1.61$ & 73.07 \\
Diclofenac sodium & 10 & $19.90 \pm 0.53^{*}$ & 25.98 \\
MECN & 50 & $54.70 \pm 1.83^{*}$ & 59.54 \\
MECN & 100 & $29.90 \pm 0.66^{*}$ & 75.24 \\
MECN & 200 & $18.30 \pm 1.25^{*}$ & -1.62 \\
Glib & 10 & $75.1 \pm 2.01$ & 51.05 \\
Glib + Diclofenac-sodium & $10+10$ & $36.20 \pm 1.77^{\text {a }}$ & 32.34 \\
Glib + MECN & $10+50$ & $50.00 \pm 1.53$ & 62.11 \\
Glib + MECN & $10+100$ & $28.00 \pm 2.13$ & 72.94 \\
Glib + MECN & $10+200$ & $20.00 \pm 1.34$ &
\end{tabular}

Each value is presented as the Mean \pm SEM $(n=5)$. MECN = Methanolic extract of. Crataeva nurvala leaves; Glib = Glibenclemide.

${ }^{*} p<0.001$ compared with the control group (Dunnett's test).

${ }^{a} p<0.001$ compared with the Diclofenac sodium treated group (Bonferroni's test).

$\mathrm{E}_{2}$ ), NO (Nitric oxide), kinins, protons, SP (Substance P) released by the glutamate and more glutamate in the dorsal horn. MECN may be blocked the NMDA (N-methyl- Daspartate) and non-NMDA receptors as well as inhibiting the release of $\mathrm{NO}$ or some NO-related substances that are present in peripheral, spinal and supraspinal sites of action $[15,28]$.

\section{Involvement of opioid system and ATP-sensitive $\mathrm{K}^{+}$channel pathway}

To further investigate the participation of opioid receptor system we investigated the effect of naloxone (a nonselective opioid receptor antagonist) against the analgesic activity of MECN in both the hot plate and tail immersion tests. The data obtained showed that the analgesic effect produced by MECN was reversed by naloxone. It was reported that both in tail-immersion and hot-plate tests thermal stimuli influenced the spinal (through $\mu 2$ and $\delta$ opioid receptors) and the supraspinal (through $\mu 1 / \mu 2$ opioid receptors) reflex respectively [29,30]. Since naloxone succeeds to antagonize the analgesic activity, thus the analgesic activity of MECN seems to be related to opioid receptor. On the other hand, glibenclamide, an ATP sensitive $\mathrm{K}^{+}$channel blocker did not significantly alter the antinociceptive effect of the extract (Table 6), it is speculated that the antinociceptive mechanism may not involve with the opening of ATP sensitive $\mathrm{K}^{+}$ channel pathway.

\section{Conclusion}

The results of the present study indicates that MECN exhibited significant antinociceptvie activity at all the tested doses in mice. The effect is dose dependent and statistically significant particulary at 100 and $200 \mathrm{mg} / \mathrm{kg}$ doses. The reversal effect by naloxone indicates the involvement of opioid and glutamate pathway in the antinociceptive effect of MECN. This indicates the presence of analgesic phytochemical(s) in the plant extract. Further studies are required to carry out antinociceptive activity test using isolated pure compound.

\section{Competing interests}

The authors declare that they have no competing interest.

\section{Authors' contributions}

MZI designed and coordinated the study. MM conducted the study. MM and MZI performed the statistical analysis, data interpretation and drafting the

manuscript. Both authors are involved in the critical evaluation and approved the final manuscript.

\section{Acknowledgements}

We are grateful to Professor Dr. Bidyut Kanti Datta, Chairman, Department of Pharmacy, Stamford University Bangladesh for his permission to use the facility of Pharmacology laboratory for this research. We also acknowledge the help of Sarwar Hossain, Partha Sarothi Bhattacharjee, Fatema Wahid and Shamima Irin for their assistance in animal handling and management.

\section{Author details}

${ }^{1}$ College of Pharmacy, Dongguk University, Goyang 410-820, Republic of Korea. ${ }^{2}$ Department of Pharmacy, Stamford University Bangladesh, 51 Siddeswari Road, Dhaka 1217, Bangladesh.

Received: 16 May 2014 Accepted: 19 September 2014 Published: 24 September 2014

\section{References}

1. Kirtikar KR, Basu BD: Indian Medicinal Plants. 2nd edition. Dehradun: International Book Publisher; 2005.

2. Ghani A: Medicinal Plant of Bangladesh with Chemical Constituents and Uses. 2nd edition. Dhaka: Asiatic Society of Bangladesh; 1998.

3. Bhattacharjee A, Shashidhara SC, Aswathanarayana: Phytochemical and ethno-pharmacological profile of Crataeva nurvala Buch-Hum (Varuna): a review. Asian Pac J Trop Biomed 2012, 2:S1162-S1168.

4. Gagandeep M, Kalidhar SB: Chemical constituents of Crataeva nurvala (Buch.-Ham.) leaves. Ind J Pharm Sci 2006, 68:804-806.

5. Khattar V, Wal A: Utilities of Crataeva nurvala. Int J Pharm Pharmaceut Sci 2012, 4:21-26.

6. Geetha T, Varalakshmi P, Latha RM: Effect of triterpenes from Crataeva nurvala stem bark on lipid peroxidation in adjuvant induced arthritis in rats. Pharmacol Res 1998, 37:191-195. 
7. Shirwaikar A, Setty M, Bommu P: Effect of lupeol isolated from Crataeva nurvala Buch.-Ham. stem bark extract against free radical induced nephrotoxicity in rats. Ind J Exp Biol 2004, 42:686-690.

8. Sikarwar MS, Patil MB: Antidiabetic activity of Crateva nurvala stem bark extracts in alloxan-induced diabetic rats. J Pharm Bioall Sci 2010, 2:18-21.

9. Walker CIB, Trevisan G, Rossato MF, Franciscato C, Pereirac ME, Ferreira J, Manfron MP: Antinociceptive activity of Mirabilis jalapa in mice. J Ethnopharmacol 2008, 120:169-175.

10. Eddy NB, Leimbach D: Synthetic analgesics: II. Dithienylbutinyl and Dithienylbutylamines. J Pharmacol Exp Ther 1953, 107:385-393.

11. D'Amour FE, Smith DL: A method for determining loss of pain sensation. J Pharmacol Exp Ther 1941, 72:74-79.

12. Sulaiman MR, Mohamad TAT, Mossadek WMS, Moin S, Yusof M, Mokhtar AF, Zakaria ZA, Israf DA, Lajis N: Antinoceciptive activity of the essential oil of Zingiber zerumbet. Planta Med 2010, 76:107-112.

13. Santos ARS, Calixto JB: Further evidence for the involvement of tachykinin receptor subtypes in formalin and capsaicin models of pain in mice. Neuropeptides 1997, 31:381-389.

14. Santos ARS, Miguel OG, Yunes RA, Calixto JB: Antinociceptive properties of the new alkaloid, cis-8, 10-di-N-propyllobelidiol hydrochloride dihydrate isolated from Siphocampylus verticillatus: Evidence for the mechanism of action. J Pharmacol Exp Ther 1999, 289:417-426.

15. Beirith A, Santos ARS, Calixto JB: Mechanisms underlying the nociception and paw oedema caused by injection of glutamate into the mouse paw. Brain Res 2002, 924:219-228.

16. Khan H, Saeed M, Gilani AUH, Khan MA, Khan I, Ashraf N: Antinociceptive activity of aerial parts of Polygonatum verticillatum: Attenuation of both peripheral and central pain mediators. Phytother Res 2011, 25:1024-1030.

17. Mohamad AS, Akhtar MN, Khalivulla SI, Perimal EK, Khalid MH, Ong HM, Zareen S, Akira A, Israf DA, Lajis N, Sulaiman MR: Possible participation of nitric oxide/cyclic guanosine monophosphate/protein kinase C/ATP-sensitive $\mathrm{K}(+)$ channels pathway in the systemic antinociception of Flavokawin B. Basic Clin Pharmacol Toxicol 2011, 108:400-405.

18. Perimal EK, Akhtar MN, Mohamad AS, Khalid MH, Ming OH, Khalid S, Tatt LM, Kamaldin MN, Zakaria ZA, Israf DA, Lajis N, Sulaiman MR: Zerumbone-induced antinociception: Involvement of the I-argininenitric oxide-cGMP-PKC- $\mathrm{K}^{+}$ ATP channel pathways. Basic Clin Pharmacol Toxicol 2011, 108:155-162.

19. Hiruma-Lima CA, Gracioso JS, Bighetti EJB, Germonsen-Robineou L, Souza-Brito ARM: The juice of the fresh leaves of Boerhaavia diffusa $\mathrm{L}$. (Nyctaginaceae) markedly reduces pain in mice. J Ethnopharmacol 2000, 71:267-274.

20. Turner RA: Screening Methods in Pharmacology. New York: Academic Press; 1965:158.

21. Choi J, Kyung-Tae L, Sei-Young Y, Chang-Duk K, Hyun-Ju J, Hee-Juhn P. Antinociceptive and antiinflammatory effects of Nigaichigoside F1 and 23- hydroxyl tormentic acid obtained from Rubus coreanus. Biol Pharm Bull 2003, 26:1436-1441.

22. Koster R, Anderson M, De-Beer EJ: Acetic acid for analgesic screening. Fed Proc 1959, 18:412.

23. Sanchez-Mateo CC, Bonkanka CX, Hernandez-Perez M, Rabanal RM: Evaluation of the analgesic and topical anti-inflammatory effects of Hypericum reflexum L. fil. J Ethnopharmacol 2006, 107:1-6.

24. Julius D, Basbaum Al: Molecular mechanisms of nociception. Nature 2001, 413:203-210.

25. Tjølsen A, Berge OG, Hunskaar S, Rosland JH, Hole K: The formalin test: an evaluation of the method. Pain 1992, 51:5-17.

26. Correa $C R$, Calixto JB: Evidence for participation of $B_{1}$ and $B_{2}$ kinin receptor in formalin induced nociceptive response in mouse. British $J$ Pharmacol 1993, 110:193-198.

27. Lapa JA, Souccar C, Lima-Landman MTR, Castro MSA, Lima TCM: Metodos de avaliacao da atividade farmacologica de plantas medicinais. In Sociedade Brasileira de Plantas Medicinais. ; 2003:64-66.

28. Sakurada T, Matsumura T, Moriyama T, Sakurada C, Ueno S, Sakurada S: Differential effects of intraplantar capsazepine and ruthenium red on capsaicin-induced desensitization in mice. Pharmacol Biochem Behav 2003, 75:115-121.
29. Jinsmaa $Y$, Okada $Y$, Tsuda $Y$, Sasak Y, Ambo A, Bryant SD, Lazarus LH: Novel 2', 6 '-dimethyl-L-tyrosine-containing pyrazinone opioid mimetic $\mu$-agonists with potent antinociceptive activity in mice. J Pharmacol Exp Ther 2004, 309:432-438.

30. Jinsmaa $Y$, Fujitab Y, Shiotanib K, Miyazakic A, Lib T, Tsuda Y, Okada Y, Amboe A, Sasakie Y, Bryanta SD, Lawrence H, Lazarus LH: Differentiation of opioid receptor preference by [Dmt1] endomorphin- 2-mediated antinociception in the mouse. Eur J Pharmacol 2005, 509:37-42.

doi:10.1186/1472-6882-14-354

Cite this article as: Moniruzzaman and Imam: Evaluation of antinociceptive effect of methanolic extract of leaves of Crataeva nurvala Buch.-Ham.. BMC Complementary and Alternative Medicine 2014 14:354

\section{Submit your next manuscript to BioMed Central and take full advantage of:}

- Convenient online submission

- Thorough peer review

- No space constraints or color figure charges

- Immediate publication on acceptance

- Inclusion in PubMed, CAS, Scopus and Google Scholar

- Research which is freely available for redistribution 